\title{
COVID -19 pandemic is a worldwide typical biopsychosocial crisis
}

\author{
Saad Ahmed Ali Jadoo ${ }^{*}$
}

\begin{abstract}
:
Since December 2019, the world has been stunned by the speed of the spread of the COVID-19. All the possibilities were likely, except that people would hide in their homes for fear of contracting the disease, as it was very unlikely. The lockdown was imposed severely, and people panicked, and their interest has limited to providing food and caring for health and family. The effect of isolation and the prevention of social interaction was apparent in the individuals' psychological behavior. Unfortunately, the incidence of depression, anxiety, and domestic violence increased, which negatively impact family stability in the short and medium-term. The pathological, psychological, and social impact of COVID-19 imposes a framework for dealing with the pandemic based on the biopsychosocial model.

Keywords: COVID-19, pandemic, Biopsychosocial model, Crisis
\end{abstract}

\section{Background}

When the novel coronavirus outbreak first hit Wuhan City, China, in December 2019, the lockdown imposed on more than 11 million people was extraordinary [1]. People were severely shocked. All social activities have ceased, except for the interest in health and the provision of food. The psychological reaction was positive at first with singing and sometimes screaming from windows and balconies. However, the following weeks' psychological impact developed to a marked increase in the incidence of depression, anxiety, and suicide attempts.

In contrast, the psycho-social impact was evident in the unprecedented increase in domestic violence rates. We were following Wuhan's situation with feelings of amazement, sympathy, and sometimes indifference; however, it never crossed our minds that we would go through the same experience later. The case in Wuhan city was brilliantly copied and distributed to most towns and villages of the world. Theoretically, the situation can be described as a typical picture of the biopsychosocial model of health and illness, a patientcentered approach set first by the American Psychiatrist George L. Engle in 1977.

Unlike the biomedical model and the social model, the Biopsychosocial model states that the determination of health and disease depends on dynamic interactions between three entities, including the biological, psychological, and social factors. The interaction of these factors significantly helps in

*Correspondence: drsaadalezzi@gmail.com

${ }^{1}$ Department of Public Health, Faculty of Medicine, Bezmialem Vakif University, Istanbul, Turkey

Full list of author information is available at the end of the article determining the cause, manifestation, and outcome of wellness and disease, i.e., the biopsychosocial model provides a complete understanding of diseases [3]. To clarify the idea more, Biopsychosocial terms should be divided and explained concerning COVID-19 disease (figure 1).

The 'bio' entity concerns with biological aspect and its impact on health. Considering the pandemic of COVID-19, the disease's causative agent is a lethal member of a large Coronaviruses group called SARS-CoV-2 [4]. Although bats are the first accused in Corona disease, yet the Coronavirus was found with $96 \%$ of its genome shared with SARS-CoV-2 in single species of bats (Rhinolophus affinis) in China [5]. Viruses and other pathogens exist in animals for tens or hundreds of years and do not transmit to humans except through a mechanism called Zoonotic spillover [6]. For the pathogen to infect a person, it must overcome a series of barriers provided by the natural ecosystem to protect humans. The direct human intervention brought about severe changes in the ecosystem, which facilitated the transmission (spillover) process [7]. In short, bats live in caves far from humans; however, humans made unnatural interference in the life of bats and brought the virus and transmitted it to others, not the bats.

The 'psycho' entity concerns psychological aspects such as thoughts, emotions, or behaviors. Considering the COVID-19 disease, the quarantine and the sudden change in lifestyle were the most significant cause of the severe deterioration in the population's psychological status. Serafini et al. [8] reviewed the literature about the psychological impact of COVID-19 on the general population. A broad range of psychological reactions began from the fear of disease and the fear of being a disease vector [9]. Anxiety was linked to the new situation that 
imposed a feeling of loneliness [8-10]. The continuation of quarantine restrictions had a significant impact on the development of anxiety into more complex emotions such as insomnia, depression, boredom, and anger [8-11].

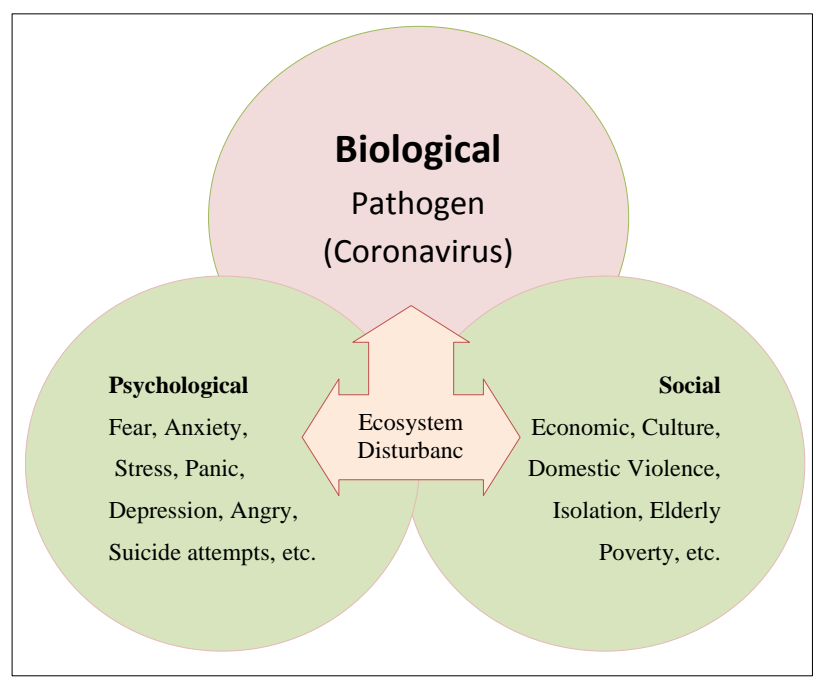

Figure 1: Biopsychosocial model for COVID-19 pandemic

The 'social' entity concerns social aspects such as influencing people's health as individuals, groups, and communities. The Coronavirus pandemic and the economic crisis are two sides of the same coin [12]. The unregulated policies in dealing with the epidemic led to social impacts that negatively influenced the people's ability to bear the burdens of COVID-19 pandemic. The world appeared unready to face such a crisis [13]. The most affected social groups were the poor and those with low incomes, especially in countries that did not take adequate measures to ensure food security during the pandemic [14]. The elderly and people with chronic diseases were more likely to contract the disease, and therefore it was difficult for them to cope with isolation and the lack of interaction with others. The pandemic caused an imbalance in the family. We were often unable to explain what is going on to our young children. Even the threshold of patience comes down, and the feelings could not be controlled often, which resulted in a significant exacerbation of domestic violence [15].

Furthermore, the inability of family members to fulfill their social role may trigger problems and causing increased tension that may lead to more biological or psychological problems. The overlap between the bio, psycho, and social status among the coronavirus patients very prominent. It is not an individual case or specific to society or group. On the contrary, it is a general case that is applicable everywhere.

\section{Conclusion}

In conclusion, the study of the COVID-19 pandemic in its three dimensions (bio-psych-social) helps develop an appropriate and effective strategy for treating patients, particularly the elderly and those with social and mental health problems.

\section{Funding}

The author received no financial support for the research, authorship, and/or publication of this article.
Availability of data and materials

Data will be available by emailing drsaadalezzi@gmail.com

\section{Authors' contributions}

Saad Ahmed Ali Jadoo (SAAJ) is the principal investigator of this manuscript. SAAJ is the responsible author for the study concept, design, writing, reviewing, editing, and approving the manuscript in its final form. SAAJ has read and approved the final manuscript.

Ethics approval and consent to participate

We conducted the research following the Declaration of Helsinki. However, Viewpoint Articles need no ethics committee approval.

\section{Consent for publication}

Not applicable

Competing interest

The author declares that he has no competing interests

Author details

${ }^{1}$ Department of Public Health, Faculty of Medicine, Bezmialem Vakif University, Istanbul, Turkey.

\section{Open Access}

This article is distributed under the terms of the Creative Commons $\begin{array}{llll}\text { Attribution } & 4.0 & \text { International }\end{array}$ (http://creativecommons.org/licenses/by/4.0/), which permits unrestricted use, distribution, and reproduction in any medium, provided you give appropriate credit to the original author(s) and the source, provide a link to the Creative Commons license, and indicate if changes were made. The Creative Commons Public Domain Dedication waiver (http://creativecommons.org/publicdomain/zero/1.0/) applies to the data made available in this article, unless otherwise stated.

\section{Article Info}

Received: 13 August 2020

Accepted: 17 August 2020

Published: 17 August 2020

\section{References}

1. World Health Organization, Novel Coronavirus (2019-nCoV) SITUATION REPORT -1, 21 JANUARY 2020. Available from: https://www.who.int/docs/default-source/coronaviruse/situationreports/20200121-sitrep-1-2019-ncov.pdf, [Accessed on 17 August 2020]

2. Engel GL: The need for a new medical model: a challenge for biomedicine. Science 1977; 196:129-136.

3. Engel GL: The clinical application of the biopsychosocial model. Am J Psychiatry 1980; 137:535-544.

4. Su S, Wong G, Shi W, Liu J, Lai ACK, Zhou J, et al. Epidemiology, genetic recombination, and pathogenesis of coronaviruses. Trends Microbiol. 2016;24(6):490-502. doi: 10.1016/j.tim.2016.03.003

5. Zhou P, Yang X, Wang X, Hu B, Zhang L, Zhang W, et al. A pneumonia outbreak associated with a new coronavirus of probable bat origin. Nature 579, 270-273 (2020). https://doi.org/10.1038/s41586-020-2012-7

6. Plowright R, Parrish C, McCallum H, Hudson PJ, Ko AI, Graham AL, Lloyd-Smith JO, et al. Pathways to zoonotic spillover. Nat 
Rev Microbiol2017; 15: 502-510. https://doi.org/10.1038/nrmicro.2017.45

7. Lindahl JF, Grace D. The consequences of human actions on risks for infectious diseases: A review. Infection Ecology and Epidemiology2015; $\quad 3$ : 30048. https://doi.org/10.3402/iee.v5.30048

8. Serafini G, Parmigiani B, Amerio A, Aguglia A, Sher L, Amore M. The psychological impact of COVID-19 on the mental health in the general population. QJM: An International Journal of Medicine.2020;113(8):531-537

https://doi.org/10.1093/qjmed/hcaa201

9. Torales J, O'Higgins M, Castaldelli-Maia JM, Ventriglio A. The outbreak of COVID-19 coronavirus and its impact on global mental health. Int J Soc Psychiatry 2020; 66:317-320.

10. Khan S, Siddique R, Li H, Ali A, Shereen MA, Bashir N, et al. Impact of coronavirus outbreak on psychological health. J Glob Health 2020; 10:010331.

11. Lee M, You M. Psychological and behavioral responses in South Korea during the early stages of coronavirus disease 2019 (COVID-19). Int J Environ Res Public Health 2020; 17:2977.
12. United Nation, industrial development organization, coronavirus: the economic impact-10 July 2020, A health pandemic or a pandemic for the economy? April 2020 and some early evidence of firms' perceptions. Avaiable from: https://www.unido.org/stories/coronavirus-economic-impact-10july-2020 [Accessed 17 August 2020]

13. Ali Jadoo SA. Was the world ready to face a crisis like COVID19? Journal of Ideas in Health 2020;3(1):123-4. Available from: https://www.jidhealth.com/index.php/jidhealth/article/view/45

14. United Nation, Everyone Included: Social Impact of COVID-19, Department of Economic and Social Affairs. Available from: https://www.un.org/development/desa/dspd/everyone-includedcovid-19.html [Accessed 17 August 2020]

15. Toprak Ergönen A, Biçen E, Ersoy G. Domestic Violence During The COVID-19 Pandemic. Bull Leg Med 2020;25(COVID-19 Sp.I.):48-57. Available from: https://www.adlitipbulteni.com/atb/article/view/1408 